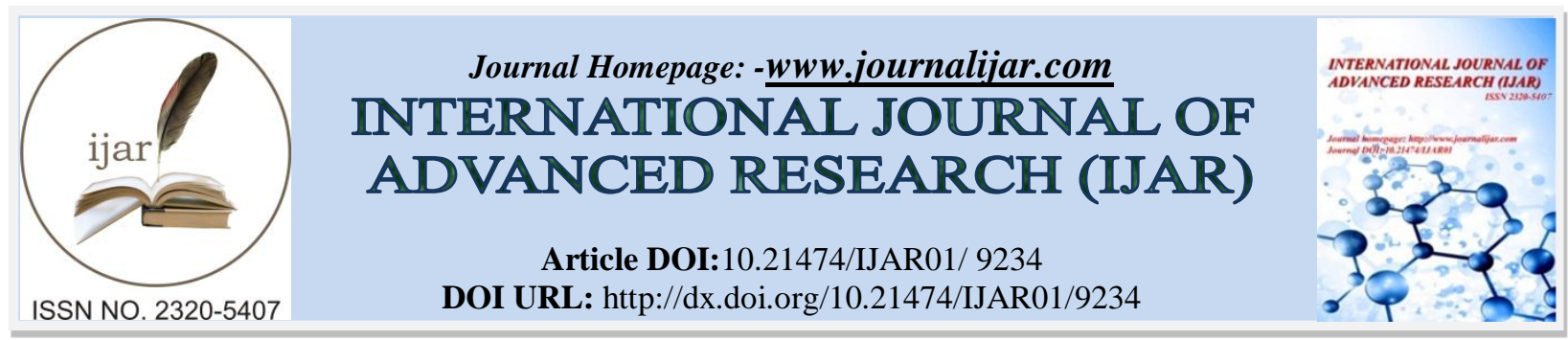

RESEARCH ARTICLE

\title{
REGULATION OF THE MINISTER OF AGRICULTURE NUMBER 26/2016 : PROTECTION BUSINESS OF THE BENEFITS OF MARKETING BREEDERS OF BROILER TO DISPARITY OF HIGH PRICES.
}

\author{
Siti Naviah $^{1}$, Z. Fanani ${ }^{2}$, B.A. Nugroho ${ }^{2}$, IH.Djunaidi ${ }^{2}$. \\ 1. Postgraduate student of animal science, brawijaya university. \\ 2. Postgraduate lecturer of animal science, brawijaya university.
}

\section{Manuscript Info}

Manuscript History

Received: 08 April 2019

Final Accepted: 10 May 2019

Published: June 2019

Key words:-

Private Profit, Competitiveness,

Ministerial Regulation.

\begin{abstract}
Broilers include modern lines that have developed in Indonesia because they have efficient advantages in products and adaptability in tropical environments. However, the absence of rules regarding the stipulation of the basic price of production factors and the selling price of chickens living in the breeders' level has resulted in the absence of business continuity protection due to profits obtained under the Cost of Production (HPP). The existence of the Minister of Agriculture Regulation Number 26/2016 which regulates the Supply, Distribution, and Monitoring of broiler and how the impact on the sustainability of its business is due to the high production price disparity. This study aims to determine whether the determination of the ministerial regulation provides protection for farmers in terms of guaranteed benefits, competitive advantage and comparability. This study uses descriptive methods, using the Policy Analysis Matrix (PAM) tool. The results of the study show that: Private profit is positive, as well as Social benefits, in the condition of DOC prices in accordance with the regulations of Permentan, private profit increases, as well as its competitiveness with the Performance Index (IP) according to the standard.
\end{abstract}

Copy Right, IJAR, 2019,. All rights reserved.

\section{Introduction:-}

The broiler is the highest population of poultry in Indonesia, where East Java ranks second after West Java with a population of $163,919,118$ tails, production of 166,149 tons with a growth rate of $2 \%$, target production in 2015 of 274.70 tons by 2019 amounting to 335.56 tons (Directorate General of Animal Husbandry, 2015). In accordance with the Ministry of Agriculture's strategic plan for 2013-2019 (RI PERMEN number 19 / Permentan / HK. 140/4/2015), the government encourages broiler exports starting from 2015 with ASEAN market goals, the reason is because national consumption of chicken is only as large as $8 \mathrm{~kg}$ per capita per year, while in Ghana to meet the needs of daily animal protein comes from broilers (Kwadzot et al, 2013). The broiler is the highest population of poultry in Indonesia, where East Java ranks second after West Java with a population of 163,919,118 units, production of 166,149 tons with a growth rate of $2 \%$, target production in 2015 of 274.70 tons by 2019 amounting to 335.56 tons (Directorate General of Animal Husbandry, 2015).

The production of domestic Day Old Chicken (DOC) reaches 50 million / head/week, national consumption reaches 41 million exports per week, this condition causes Indonesia to overload DOC and has the opportunity to export in 
the form of processed broiler to Japan and the Middle East (Tobing, 2015). While in Lamongan, East Java, the broiler population has increased by 44,915,486 (East Java Province Animal Husbandry Service, 2010-2014). This agribusiness is carried out in partnership with poultry (Nucleus Company) companies, the position of farmers as plasma only provides land, cages, equipment, and labor, while DOC (Day Old Chick), feed, medicine, etc. are provided by the company as the point. The problem is price volatility at the level of consumers and breeders, which is why the government sets broiler price standards in the market through Minister of Agriculture Regulation No. 26/2016 on Provision, Circulation and Monitoring of broiler which came into force since 9 December 2016 with the aim of reducing disparity high price. In this regulation the basic price for broiler (day old chicken) is Rp. 4,800 per chick, the price of broiler in the cage is Rp. 18,000, and the market price is Rp. 32,000 per kilogram, whereas the price of chicken at the producer level is at around Rp. 5,000-6,000 per chick, the price of chicken is Rp. 13,000 - Rp. 14,300 per kg, while the Cost of Production (HPP) is Rp. 17,000 per kg (TROBOS edition 198/2016). In focus of this affect the sustainability of the production business at the farmer level due to the high production price disparity with the enactment of Minister of Agriculture Regulation No. 26/2016, this is the starting point for the next step to mainly increase product competitiveness. An analysis is carried out to what extent this regulation policy provides protection to farmers in terms of guaranteed benefits, competitive advantage and comparability, this problem approach is carried out by survey and descriptive methods with the Policy Analysis Matrix (PAM) tool.

\section{Research Purpose:-}

Based on the formulation of the problem above, the objectives of this study are as follows:

1. Analyzing the Private and Social Benefits of Broiler Production Business at the Farmer Level.

2. Analyzing the increase in profits of broilers at the breeders level.

3. Analyzing the increase in the competitiveness of broilers at the breeders level.

\section{Research Methods:-}

This study uses a combination of surveys and quantitative descriptive methods based on the application of the Policy Analysis Matrix (PAM) analysis tool used to know "private returns" and "social returns", comparative advantage (economic analysis) with indicators Domestic Resource Cost Ratio ( DRCR) and competitive advantage (financial analysis) use the indicator of Private Cost Ratio (PCR). Financial analysis is calculated based on market prices which include costs tradable inputs and domestic factors (differentiated into foreign and domestic components), revenues and profits, while economic analysis is based on social prices in the presence of Minister of Agriculture Regulation No. 26/2016.

Table 1:-Components for compiling Policy Analysis Matrix

\begin{tabular}{|c|c|c|c|c|}
\hline \multirow[t]{2}{*}{ Component } & \multirow[t]{2}{*}{ Income } & \multicolumn{2}{|c|}{ Production Cost } & \multirow[t]{2}{*}{ Profit } \\
\hline & & Tradable & Non-Tradable & \\
\hline Private & $\mathrm{A}$ & $\mathrm{B}$ & $\mathrm{C}$ & $\mathrm{D}$ \\
\hline Price & & & & \\
\hline Social & & & & \\
\hline Price & $\mathrm{E}$ & $\mathrm{F}$ & $\mathrm{G}$ & $\mathrm{H}$ \\
\hline Divergence & $\mathrm{I}=\mathrm{A}-\mathrm{E}$ & $\mathrm{J}=\mathrm{B}-\mathrm{F}$ & $\mathrm{K}=\mathrm{C}-\mathrm{G}$ & $\mathrm{L}=\mathrm{D}-\mathrm{H}$ \\
\hline
\end{tabular}

Source : Monke and Pearson (1995)

Information :

A: Income private

B: Cost Input Tradabl

C: Cost Input Non-Tradable

D: Profit

E: Income social

F: Cost Input tradable Social

G: Cost Input Non-tradable Social

H: Profit social

I: Transfer output

J: Transfer input tradable

$\mathrm{K}$ : Transfer factor

L: Net Transfer

While the analysis of comparative advantage competitiveness uses the following formula: 
When the value is obtained:

$\mathrm{DRCR}$ : DRC/SER

Where :

DRCR: Ratio of domestic resource costs (\%)

DRC: Domestic resource costs used (Rp)

SER: Shadow exchange rate (Rp/US\$)

When the value is obtained:

DRCR > 1, means broiler agribusiness is not economically efficient or does not have a comparative advantage.

DRCR <1, means broiler agribusiness is efficient and economically has a comparative advantage.

DRCR $=1$ means broiler agribusiness in balance

The competitive advantage of using formulas:

PCR: DRC/ NTR

Where :

PCR: the ratio of domestic resource costs or actual price (\%)

DRC: domestic resource costs based on the actual price (Rp)

NTR : middle value of rupiah (IDR / US \$)

If the value is obtained:

PCR $>1$, means that broiler agribusiness is financially inefficient or does not have a competitive advantage.

PCR $<1$, means broiler agribusiness is efficient and financially has a competitive advantage.

$\mathrm{PCR}=1$, means broiler agribusiness in balance

Determination of the location of the study was conducted purposively in Lamongan District on the basis of having the prospect of $44,915,845$ poultry population $24.979 \%$ from the East Java population $179,830,682$, where East Java alone $12.135 \%$ of the national population and constituted the number two broiler population center after West Java in Indonesia. The study sample consisted of plasma breeder as many as 200 breeders $(88.49 \%)$ with a business scale of under 5000 birds and over 5000 as many as 26 breeders (11.50\%) with 12 partner companies.

\section{Research Result And Discussion:-}

Lamongan Regency has the largest population prospect of poultry in East Java, geographically located at 651'54 "723'06" South Latitude and 11233'45 "- 11233'45" East Longitude, with an area of 1,812.8 km2 or $+3.78 \%$ of the total area of East Java Province. The coastline length of $47 \mathrm{~km}$, the area of sea waters of $902.4 \mathrm{~km} 2$, is calculated 12 miles from sea level. The number of business scale under 5000 heads is around 200 breeders $(88.49 \%)$, while over 5000 breeders are 26 breeders $(11.50 \%)$, while the area of cages owned by farmers is between $200-2000 \mathrm{~m}^{2}$, with an average density of 8 broilers/ $\mathrm{m}^{2}$. The results of a study conducted by Majid, et al (2014) in Perak Malaysia showed that the variable broiler price, feed conversion rate (FCR), average body age and mortality rate, the maintenance system significantly affected farmer profits, except for farm size. The study (Khairisat, 2013) in the Jordan district concluded that groups of small farmers (5,000-10,000 broiler) lost money, depending on credit facilities, financially, the variation in high input-output prices resulted in stabilized income, although it had managed to maintain mortality under normal circumstances. But the marginal efficiency of capital is not obtained due to the high cost of production, this is consistent with the study (Abdallah et al., 2013) large-scale broiler breeders are more profitable than the small scale, while labor factors significantly reduce profits (Tuffour et al, 2013). So it is recommended the certainty of the availability of day-old chickens (DOC) at lower prices to reduce production costs, and the selling price can be fixed weekly or two weeks in coordination with producers, this is in accordance with the aim of the Minister of Agriculture Regulation No. 26/2016.

\section{Use of production factors:-}

In broiler agribusiness factors that influence production and include Tradable input goods include:

a. Chicken Seedlings (Day Old Chik / DOC).

In the study location according to the period of cage capacity used for breeders with a scale of $<5000$ each per production period (4 periods) DOC (strain type Hubbard, Arbor Acres) which was maintained as many as 16,242 tails or average period of 4060 tails, while for breeders scale> 5000 DOC which is maintained as many as 30,993 tails or each period has an average of 7748 tails, with a mortality rate of 4.17-4.67 percent while the standard mortality value is 4.5 percent, and harvest weight is $1.47 \mathrm{~kg}-2.08 \mathrm{~kg} /$ head, selection of Arbor Acres strains this is in accordance with the research (Yakubu, et al., 2010), the determination of broiler strain lines in Indonesia is appropriate (Nath, et al 2007). Regarding the scale of the business, it differs from the research conducted by Elsedig 
et al (2015) in Johor Malaysia where the scale was divided into three categories, namely large scale more than 150,000 tails, medium scale 30,000-150,000 head, while the small scale is less than 30,000 head. The results of the Khairisat (2013) study concluded that smallholder farmers in Jordan (5,000-10,000 broiler) lost money, depending on credit facilities. High input-output price fluctuations cause stabilization of livestock breeders income, although they have managed to maintain mortality, but the marginal efficiency of capital is not obtained due to high production costs, this is in line with the objective of stipulating Minister of Agriculture Regulation No. 26/2016 to reduce factor price disparity production with the provisions of the basic price of chicken (day old chicken) of Rp. 4,800 per chick. for a scale of $\leq 5000$ tails, this is the same as the price on a scale of $>5000$. The condition of the DOC prices before the fluctuating ministerial regulation (PUSDATIN, 2015), these price fluctuations were influenced by demand and supply which were often inappropriate, this supply was determined by the nursery company when the company imported the Grand Parent chicken which would produce a Parent Stock and finally the Stock in DOC. While Fatimah's research in Johor (2015) states that in general, all scales have shown comparative advantage (less than one DRC), this reflects technological progress in the utilization of broiler chicken production resources.

\section{Private and Social Budgets:-}

The private costs of broiler production at the research location by applying Ministerial Regulation Number $26 / 2016$ amounted to $\mathrm{Rp} 355,476,526(23,084.00 / \mathrm{kg})$ for a scale of $\leq 5000$ units and $\mathrm{Rp} \mathrm{908,869,209} \mathrm{(Rp23,834.00} \mathrm{/} \mathrm{kg),}$ for scale $\geq 5000$ units, social costs scale $\leq 5000$ units Rp. 356,162,688 (22,267.00/ kg) and Rp. $872.907,485$ (Rp. $22,353.00 / \mathrm{kg}$ ) for a scale of $\geq 5000$ tails. Private costs are greater than the social costs, this is due to the price of feed of Rp. 6,611.00 - 6,604.00 / kg, which is more expensive than the price of social feed-borne by breeders. Clearer costs, revenues, and profits (years) and (Kg) illustrated in Figure 1 and 2 below:

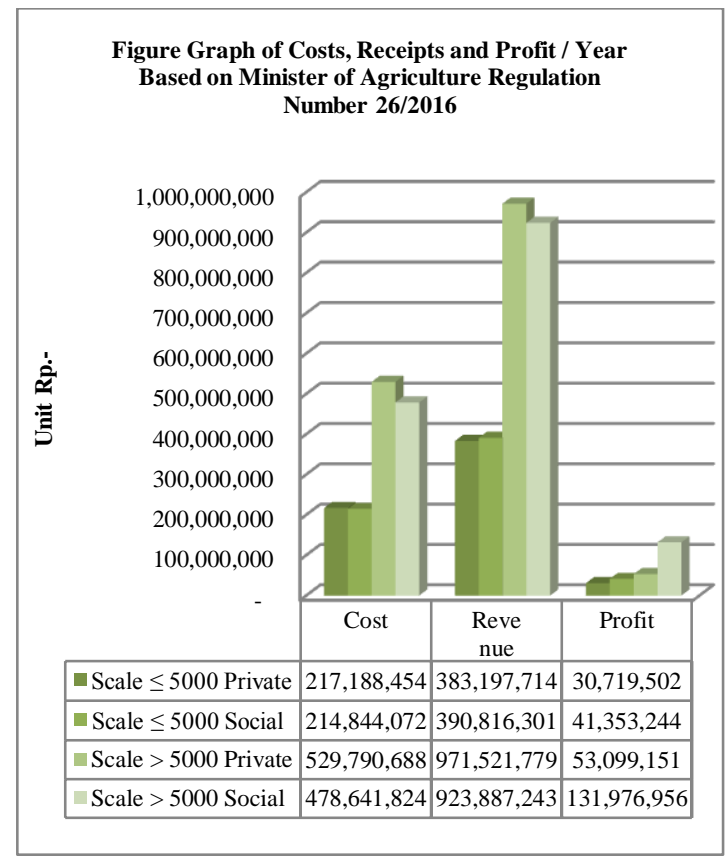

Figure 1:-Costs, Receipts, and Benefits Based on the Minister of Agriculture Regulation Number 26/2016 (Year)

Likewise, the amount of Private costs in units $(\mathrm{Kg})$, is greater than the Social costs, while the amount of Social benefits on a scale of $\leq 5000$ tails and $\geq 5000$ tails is greater than the Private profit. This condition can be concluded that the existence of Minister of Agriculture Regulation No. 26/2016 with provisions p [basic price setting for chickens (day old chicken) of Rp. 4,800 per chick, the price of live broiler in cages of Rp. 18,000, can provide profit protection on breeders due to the high disparity in the price of production costs and the guarantee of sustainability and improvement of their business. Profits are also influenced by feed prices and wages of labor, this is due to lower marginal contribution of labor to prices (Jabbar et al, 2005), another factor that influences income is mortality due to ineffective management of health programs which include vaccination, therapy antibiotics, and hygiene of cage factors (Mukherjee et al, 1994). 


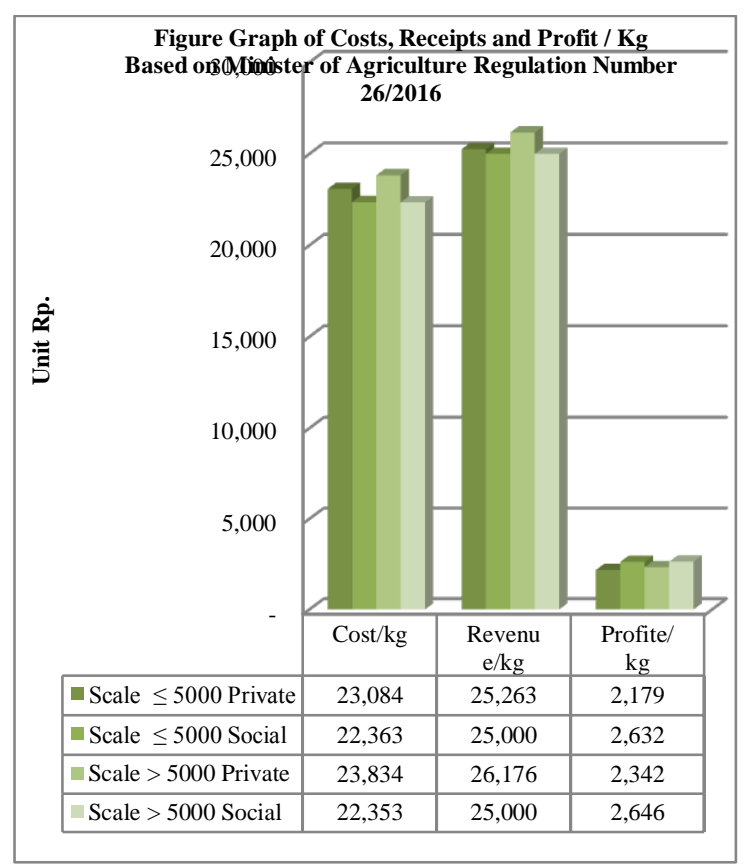

Figure 2:-Cost, Receipt, Profit Based Minister of Agriculture Regulation Number 26/2016 (kg)

\section{Efficiency Analysis:-}

Based on the graphs 1 and 2, it turns out that the Private Profit is positive, this means that the livestock business is efficient and able to compete (competitively) at the actual price level, the policy at the farmer level influences the competitiveness of the product, while the Social benefit is positive this means effort These farms are able to compete (comparatively) at the international price level without policy, this is in accordance with the opinion of Pearson et al (2005). The results of the analysis show that private benefits on both business scales are lower than social acceptance. This is due to breeders obtaining private prices of carcasses of Rp. 29,159 / kg, cheaper than the price of social carcasses of Rp. 30,651/ kg. The difference in revenues and fees provides private benefits of Rp. 27,721,188 (Rp. 2,179/ kg) for a scale of $\leq 5000$ tails and Rp. 62,652,570 (Rp. 2,342/ kg) for a scale of $>5000$ units, lower than the social benefits of Rp. 34,653,613 (Rp. 2,633 / kg) and Rp. 50,979,758 (Rp. 2,647 / kg). Increased profits can be increased by enlarging the scale of Elsedig et al's livestock business (2015).

\section{Sensitivity Analysis of Policies:-}

The sensitivity analysis used is the change in DOC prices in accordance with the revised Permentan Number 61 / Permentan / PK.230 / 12/2016 with the provisions of the DOC price of Rp.4800, - and the price of chicken Rp.18,000, - while other factors are considered constant and policy distortion (import tariff for feed ingredients, omitted). In this study the sensitivity of the change in DOC price of Rp. 5,483.00 / head to Rp.4,800, - / units according to the provisions of the revised price of Permentan or down by $12 \%$, while the price of the broiler is Rp.15,200 / tail to Rp.18,000 / tailor up 15\% while other factors remain, will increase financial efficiency and competitiveness of broiler partnerships. In the condition of DOC prices in accordance with the regulations of Permentan, private profits increased by Rp. 4,366,370.00 (16\%) or Rp. 2,179.00/ kg on a scale of $\leq 5000$ tails and Rp. $3,798,136.00(7 \%)$ or Rp. $2,632.00 / \mathrm{kg}$ on a scale of $>5000$ units. This means that there is a marketing efficiency of the DOC, both due to policy distortions and market failures, causing broiler production costs in both business scales to decline. Whereas based on the magnitude of the cost factor $(\mathrm{kg})$, output price, private profit, output transfer, net transfer on the condition of DOC (Year) prices based on Minister of Agriculture Regulation Number 26 of 2016, are shown in Figure Graph 3 below: 

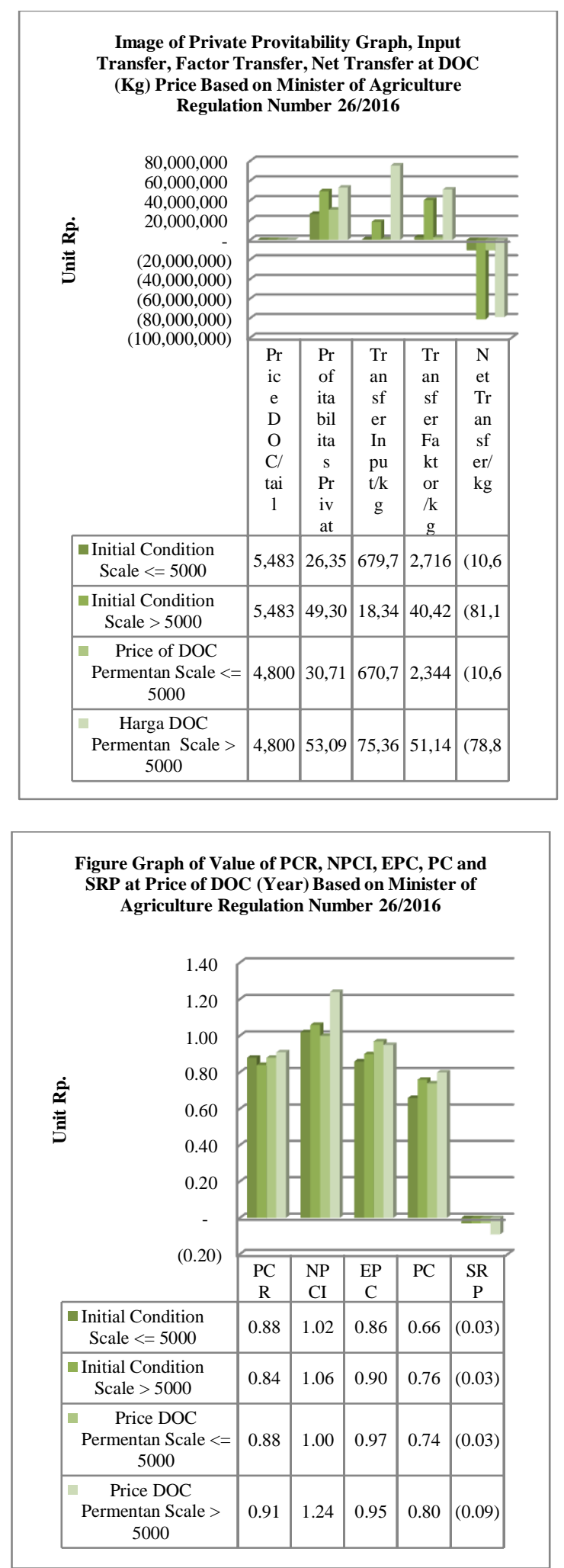

Figure 4:-Cost, Receipt, Profit Based Minister of Agriculture Regulation Number 26/2016 (kg)

Input transfers on both business scales are positive, this means that the production of broiler partnerships in Lamongan District receives subsidies as much as the value of input transfers, where the transfers are obtained aside from the price of OVD also from gas and electricity. While based on the results of the analysis of the NPCI values 
obtained 1.00, this means that the price of input tradable at domestic prices equals the social price. Net transfers on both business scales dropped from $\mathrm{Rp}-10.64$ and $\mathrm{Rp}-81.17$ to $\mathrm{Rp}-10.63$ and $\mathrm{Rp}-78.87$. The decrease in net transfers of Rp. 9,000,000 (0.08\%) and Rp. 2,230,060 (2.8\%) resulted in PC values (Profitability Coefficient) increasing from 0.66 to 0.74 and from 0.76 to 0.84 this condition indicates that the price of DOC according to the provisions of Permentan can increase private profits to 8 percent and 4 percent to social benefits. The EPC (Effective Protection Coefficient) value on both business scales increased from 0.86 to 0.97 , indicating that valueadded output in private prices increased from 86 percent to 97 percent from added value to social prices. SRP values decreased from 0.09 and 0.03 , meaning that the profits received by farmers decreased by 1 percent and 6 percent from their economic acceptance. It was concluded that the price of DOC in accordance with the provisions of the regulation resulted in low production costs, which could increase competitiveness and efficiency. Whereas to find out competitive advantage can be known based on PCR value, where based on efficient DOC prices can increase competitive advantage this can be seen from the decreasing PCR value on both business scale, which is 0.88 to 0.88 on business scale 5000 tails and 0.84 to 0.91 on a scale of $>5000$ tails. This condition indicates the magnitude of domestic factor costs needed to get added value for one foreign exchange unit (1 US \$) on both business scales decreasing 0.10 US \$ (Rp. 2,179.00) and 0.11 US \$ (Rp.2632,00).

Percent depletion value of $4 \%$ with the age of harvesting of broiler for 30 days based on the calculation of the average harvest time during the maintenance period, this condition shows good governance during the maintenance process, while the weight of harvested broiler averages $2.05 \mathrm{~kg}$, according to standard weight performance between $1,879-2.115 \mathrm{~kg}$ ) If the standard of broiler weight has not been reached, the breeders do special treatment by adding a maximum of 15 grams of vitamin and feed. The average FCR value is 1.47 , this is calculated based on the distribution of the amount of feed given in the range of total chicken harvest weight minus the amount of feed per head multiplied by the broiler population.

Based on the description, it can be seen that the value of the Performance Index (IP) of broiler farming is 320 , this indicates that management has been implemented efficiently and effectively, farmers must cooperate with the Research and Development Agency (Bano et al, 2011ab).

Table 1:-PAM Analysis Total Per (year) According to Ministerial Regulation Number 26/2016

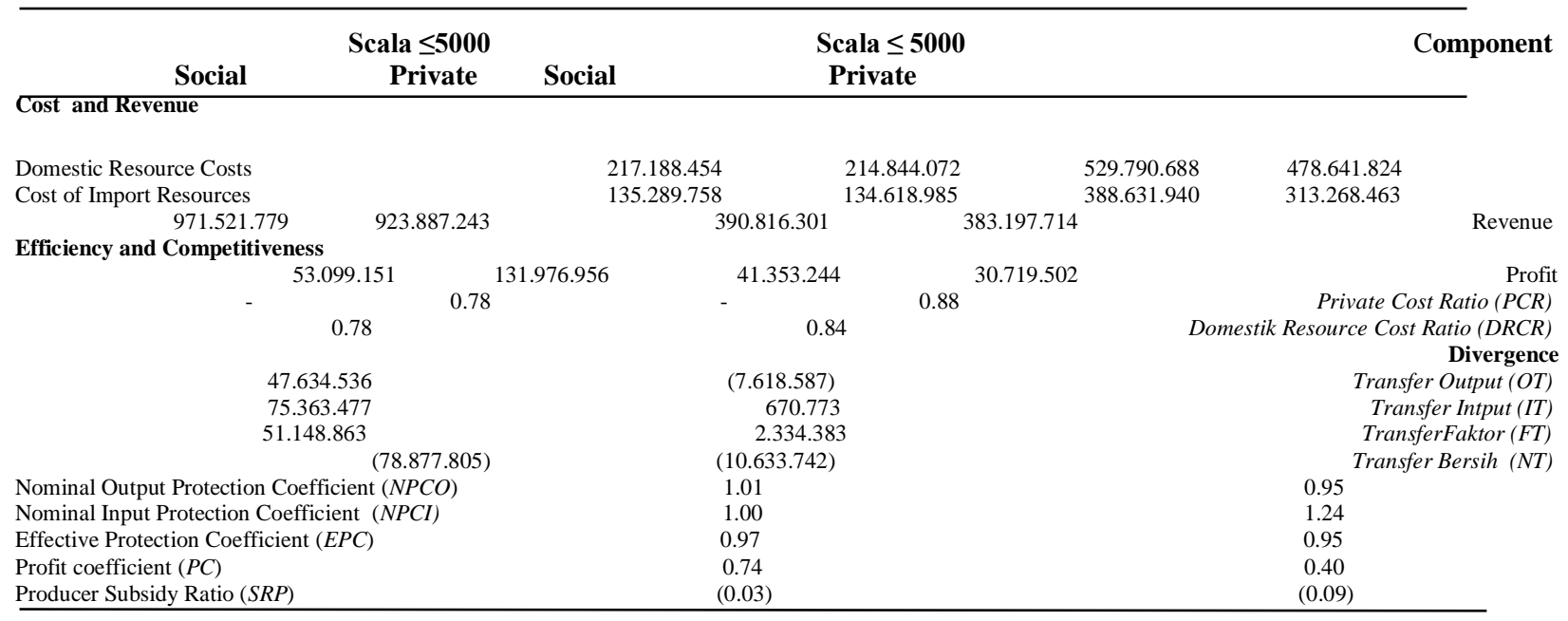


Table 2:-PAM Analysis of Total Per (Unit) Output in accordance with Ministerial Regulation Number 26/2016

\begin{tabular}{|c|c|c|c|c|}
\hline & Scala $\leq \mathbf{5 0 0 0}$ & & Scala $\leq 5000$ & Component \\
\hline Social & Private & Social & Private & \\
\hline 13.736 & 14.631 & 13.752 & 14.170 & Biaya Sumberdaya Domestik \\
\hline 8.617 & 9.203 & 8.615 & 8.914 & Biaya Sumberdaya Impor \\
\hline 25.000 & 26.176 & 25.000 & 25.263 & Penerimaan \\
\hline 2.646 & 2.342 & 2.632 & 2.179 & $\begin{array}{c}\text { Efisiensi dan Daya Saing } \\
\text { Profit }\end{array}$ \\
\hline & 0.86 & & 0.87 & Private Cost Ratio (PCR) \\
\hline & 0.84 & & 0.84 & $\begin{array}{r}\text { Domestik Resource Cost Ratio (DRCR) } \\
\text { Divergence }\end{array}$ \\
\hline & 1.176 & & 263 & Transfer Output (OT) \\
\hline & 586 & & 299 & Transfer Intput (IT) \\
\hline & 894 & & 417 & TransferFaktor $(F T)$ \\
\hline & (304) & & (454) & Transfer Bersih (NT) \\
\hline & 1.05 & & 1.01 & Nominal Output Protection Coefficient $(\mathrm{NPCO})$ \\
\hline & 1.07 & & 1.03 & Nominal Input Protection Coefficient (NPCI) \\
\hline & 1.04 & & 1.00 & Effective Protection Coefficient $(E P C)$ \\
\hline & 0.01 & & $(0.02)$ & $\begin{array}{r}\text { Profit coefficient }(P C) \\
\text { Producer Subsidy Ratio }(S R P)\end{array}$ \\
\hline
\end{tabular}

\section{Conclusions And Recommendations:-}

\section{Conclusions:-}

The results of this study draw the following conclusions:

1. Based on the calculation of positive Private Profit value, it means being able to compete (competitively) at the actual price level. Likewise, Social benefits are also positive, meaning being able to compete (comparative) at the international price level without the existence of a policy with an efficient and effective management system based on the value of the Index of Achievement in accordance with the standard.

2. Under the conditions of DOC prices in accordance with the regulations of the Ministry of Agriculture, private profits increase.

3. Based on DOC prices according to the regulations of Permentan can increase competitiveness

\section{Bibliography:-}

1. Abdallah, A., \& Al, A. (2013). Economic Analysis of Poultry ( Broiler ) Production in Amman and Irbid District in Jordan, 1(1), 24-30.

2. Bano, R., Shah, H., Sharif, M., \& Akhtar, W. (2011a). Profitability Index and Capital Turn Over in Openhouse Broiler Farming : A Case Study of District Rawalpindi, 24(1).

3. Bano, R., Shah, H., Sharif, M., \& Akhtar, W. (2011b). Profitability Index and Capital Turn Over in Open House Broiler Farming: a Case Study of District Rawalpindi. Pakistan J. Agric. Res, 24(4).

4. East Java Provincial Animal Husbandry Service, 2015. Livestock Statistics 2010-2014. Surabaya

5. Directorate General of Animal Husbandry, 2015. Ministry of Agriculture Renstra Year 2015-2019. Source: BPS, processed by Pusdatin (2013).

6. Elsedig, E. a, Mohd, M. I., \& Fatimah, M. a. (2015). Assessing the competitiveness and comparative advantage of broiler production in Johor using policy analysis matrix. International Food Research Journal, 22(1), 116-121.

7. Kwadzo, G.T.M., Dadzie, F., Osei - Asare, Y.B. \& Kuwornu, J.K.M. (2013). Consumer Preference for Broiler Meat in Ghana: A Conjoint Analysis Approach. International Journal of Marketing Studies, 5 (2).

8. Nath, M., Singh, B.P., Saxena, V.K. and Singh, R.V., 2007. Analyses of crossbreeding parameters for juvenile body weights in broiler chicken. Journal of Applied Animal Research, 32, 101-106.

9. Tobing.M, (2015). Breeders support rejecting Brazil's chicken meat imports. http://industri.kontan.co.id/new

10. Tuffour, M., \& Oppong, B. a. (2013). Profit Efficiency in Broiler Production : Evidence From Greater Accra Region of Ghana. International Journal of Food and Agricultural Economics,2(1),23-32.

11. Yakubu, A., Ayoade, J. a., \& Dahiru, Y. M. (2010). Effects of genotype and population density on growth performance, carcass characteristics, and cost-benefits of broiler chickens in north-central Nigeria. Tropical Animal Health and Production, 42(4), 719-727. 